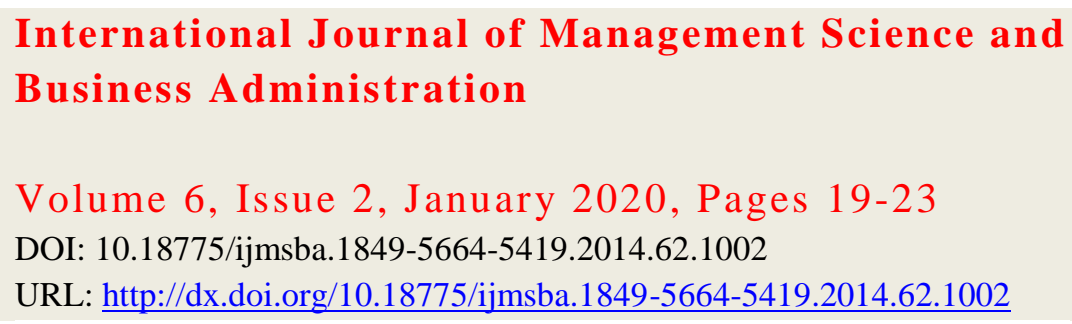

\title{
Criminal Law Framework to Combat Criminal Offenses of Corruption in Croatia and Serbia
}

\author{
${ }^{1}$ Vanda Bozic, ${ }^{2}$ Zeljko Nikac \\ ${ }^{1}$ Department of Criminal Law, Faculty of Law, Zagreb, Croatia \\ ${ }^{2}$ The Academy of Criminalistic and Police Studies, Belgrade, Serbia
}

\begin{abstract}
Corruption today is the first-rate problem of human society and the international community. In transitional countries such as Croatia and Serbia, offenses of corruption are very pronounced, especially since legal and institutional frameworks for combating corruption have not been developing for a long time. The paper deals with the notion, characteristics and dimensions of corruption in the function of discussion on criminal offenses of corruption in these countries. It gives a brief overview of the major international legal sources that Croatia and Serbia have adopted and incorporated into national legislation. The central part of the work is devoted to national legal framework for the fight against corruptive acts, a comparative legal representation and the most common criminal offenses were pointed out in more detailed. Concluding considerations are devoted to some de lege ferenda proposals to suppress criminal offenses of corruption.
\end{abstract}

Keywords: Corruption, Criminal offences, National and international legal framework, Croatia, Serbia

\section{Introduction}

Corruption today is undeniable a global problem. This phenomenon, known since the emergence of human society, has remained rooted to date by very skillfully changing its forms and adapting to social circumstances. Corruption today represents one of the biggest threats to a developed society and its legal order. Acts of corruption equally threaten the rich and poor countries, especially affected are countries in transition. Social changes in the world at the end of the last century have also affected the area of our region, which unfortunately escalated in a war conflict and enormous increase in crime rates. Corruption was an indispensable companion of this process and in some places it has become even a phenomenon that is to some extent socially acceptable. Equally threatened are both the public and private sector and citizens' trust in the state and its authorities, which led to a huge mistrust of potential foreign investors in the economy of the newly created states. After the war, Croatia started the harmonization of legal norms with the legal instruments of EU, whose member it became in 2013. In that context, Croatia adopted legal solutions and anti-corruption mechanisms and established an institutional and legal framework. Serbia is in a more difficult position because it is still in the process of applying for EU membership and is still in the process of building a legal and institutional framework. In the field of corruption Serbia is given serious recommendations by the specialized international organization GRECCO that need to be adopted and implemented. Of particular importance are chapters no. 23 and 24 of accession negotiations with the EU where the recommendations that Serbia needs to incorporate into its legislation are listed.

\section{General Considerations on Corruption}

Corruption (Lat. corruptio) implies perversion, disgrace; bribing; and is known since the earliest days of human society. One of the most famous philosophers of ancient Greece, Aristotle, pointed out that the system of ephorea at the time was conducive to the development of corruption in society because "the greatest crimes have not been committed to obtain the necessary, but surplus." In the essence of corruption is the human nature and the need for unlawful material gain, which remains to the present day of the modern era. The conceptual definition of corruption is different in contemporary doctrine and practice, so there is no uniform definition. According to the sociological concept of corruption, acts that 
violate moral and legal norms relate to the concept of general good and public interest. The legalistic view is based on ancient laws such as the Hammurabi Code and the Roman Law (Table 12). The socio-legal attitude equally respects the sociological and legal elements of corruption. The current standpoint is based on the position of the World Bank, which, under corruption, implies abuse of the public position in order to achieve private benefit. International organization for the fight against corruption Transparency International defines corruption like as abuse of power for private gain. Based on the accepted definitions, public powers (in the public or private sector), abuse of authority and unlawful property gain (for themselves or others) can be distinguished as the most important elements of corruption. The most important elements of corruption are:

- public powers (in the public or private sector),

- abuse of authority

- unlawful property gain

Manifestations of corruption can be: individual, systemic, indirect, competitive, active and passive and other forms (institutional and idiosyncratic, conventional and indirect, street, contractual and political, transactional, exiting and investing, nepotistic and autogenic). Political Corruption is grand corruption which is primarily represented among high government officials, which makes it particularly dangerous due to the great power of individuals. Petty Corruption is the kind of corruption which refers to responsible persons employed in public administration who decide on the rights of natural persons (citizens) and legal entities. Etiological dimension of corruption includes the causes and conditions of corruption that may be endogenous (personal character, motivation and initiative) and exogenous (political, social, institutional, legal and economic). Exogenous causes are mainly related to the weaknesses of the political, economic and legal system, such as the absence of adequate legal solutions and anti-corruption mechanisms. This affects the distrust of citizens in the state and its institutions and contributes to the absence of the rule of law. Victimological dimension of corruption includes the protection of victims and injured parties in corruptive acts. This dimension is of particular importance for strengthening and encouraging the position of victims to report even the smallest acts of corruption.

\section{International Legislation for Fighting Corruption}

International anti-corruption legislation encompasses the most important multilateral conventions adopted at the UN and Council of Europe levels. UN Convention against Corruption stipulates the obligation of the signatory states to envisage anti-corruption measures in their national legislation, adequate legal and institutional mechanisms for combating corruption, training of staff and the incrimination of corrupt criminal offenses in national law. Among the most important incriminations are mentioned: bribery, embezzlement, unlawful appropriation or other redeployment of property, trade in influence, abuse of office, unlawful engagement, money laundering of assets gained by a criminal offense, obstruction of justice, the responsibility of legal persons and punishment of all persons who have contributed to the commission of the criminal offense. UN Convention Against Transnational Organized Crime also provides for obligation of the signatory states to incriminate corruption offenses in national legislation. Convention provides for the formation of specialized bodies to combat all forms of organized crime and the use of special investigative techniques. Regarding corruption, the Convention in a similar way determines the term, subjects and acts of the commission of corrupt criminal offenses. Criminal Law Convention on Corruption was adopted at the level of the Council of Europe which foresees the obligation to incriminate the following corruptive acts such as: bribery in the public and private sector, trade in influence, money laundering acquired by corruptive offenses and financial crime. Civil Law Convention on Corruption defines corruption as any act that relates to the direct or indirect search, offering, giving or receiving of bribes or any other unauthorized use, as well as the ability to obtain such benefits. Based on the Civil Law Convention on Corruption formed is an international expert organization GRECO - Group of States against Corruption, whose basic task is to monitor the application of the Convention in practice, prepare a report on the state of corruption in each signatory state and make recommendations for combating corruption.

\section{National Legislation for Fighting Corruption}

\subsection{Legislative of Republic of Croatia}

Croatia has become a member of the EU on July 1, 2013 and has accordingly harmonized its legislation with EU law. Criminal justice framework for the suppression of corruption is made up of several important regulations: Criminal Code, Criminal Procedure Code, Law on the Prevention of Conflict of Interest in Public Functions, Law on USKOK, Law on Prevention of Money Laundering and Financing of Terrorism, Law on Responsibility of Legal Persons for Criminal Offenses, Witness Protection Act, Law on Access to Information and the Law on International Legal Assistance in 
Criminal Matters. Criminal Code Republic of Croatia (CC RC) provides for the following corruptive offenses: Bribing and receiving bribes, Abuse of position and authority, Money laundering, Trading in influence, Giving and receiving bribes in economic business, Bribing for trading in influence, Misuse of public procurement procedure, Illegal favoritism, Receiving and giving bribes in bankruptcy proceedings, Bribing member of parliament. Amendments to the Criminal Code RC have introduced several criminal offenses, such as art.254. Misuse of public procurement procedure and art.292. Illegal favoritism. The Criminal Procedure Code Republic of Croatia (CPC RC) provides for the criminal investigation to be conducted and chaired by the Public Prosecution RC that has available the improved legal mechanisms such as the treaty of parties with regard to the admission of guilt and consequently lower sentences. Law on USKOK determines the structure, organization and competences of the Office in the fight against corruption and organized crime. It enters into the legal order of Croatia the Council Framework Decision 2005/212/PUP of 24 February 2005 on the confiscation of property gains, assets and property acquired by a criminal offense and Council Framework Decision 2002/465 / PUP of 13 June 2002 on joint investigative teams. Strategic documents have been adopted in the fight against this plague: The Strategy for the Suppression of Corruption from 2015 to 2020 and the Action Plan for 2017 and 2018 with the Strategy.

\subsection{Legislative of Republic of Serbia}

Serbia is a candidate country for EU membership and is in the process of harmonizing its legislation with EU law. Criminal justice framework for the suppression of corruption is made up of several important regulations: Criminal Code, Criminal Procedure Code, Law on Organization and Competence of State Bodies in Suppressing Organized Crime, Law on the Program for the Protection of Participants in Criminal Procedure, Law on Withdrawal of Proceeds of the Criminal Offense, Law on the Anti-Corruption Agency Zakon o agenciji za borbu protiv korupcije and Law on the Protection of Whistleblowers. Criminal Code of Serbia (CC RS) incriminates the following criminal offenses: Receipt of Bribes, Giving Bribes, Giving and receiving bribes related to voting, Abuse of the Position of a Responsible Person, Misuse of Public Procurement, Violation of employment rights and during unemployment, Trading in Influence, Abuse of Official Position, Abuse in the Privatization Process, Bribing in Execution of Economic Activities, Acceptance of a Bribe in the Execution of Economic Activities, Causing Bankruptcy, Causing False Bankruptcy and Money laundering. In early 2018, the last amendments to the Criminal Code of Serbia came into force by which Serbia criminalized several new criminal offenses involving corruption. Criminal Procedure Code of Serbia instead to the earlier investigative judges, has entrusted the investigation to the Public Prosecutor's Office of RS, to whom the criminal police is subordinated. For the collection of evidence and prosecution of suspects for corruption, great importance is given to basic (art.85-159) and special evidence (art.160-187).

Table 1: Most frequent offenses pf corruption in CC RC and CC RS

\begin{tabular}{|l|l|l|l|}
\hline \multicolumn{2}{|c|}{ CROATIA } & \multicolumn{2}{c|}{ SERBIA } \\
\hline Art.CC & Corruption criminal offence & Art.CC & \multicolumn{1}{c|}{ Corruption criminal offence } \\
\hline 251 & $\begin{array}{l}\text { Receiving and giving bribes in } \\
\text { bankruptcy proceedings }\end{array}$ & 227 & $\begin{array}{l}\text { Abuse of the Position of a } \\
\text { Responsible Person }\end{array}$ \\
\hline 252 & $\begin{array}{l}\text { Receiving bribes in economic } \\
\text { business }\end{array}$ & 228 & Misuse of Public Procurement \\
\hline 253 & $\begin{array}{l}\text { Giving bribes in economic } \\
\text { business }\end{array}$ & 245 & Money laundering \\
\hline 254 & $\begin{array}{l}\text { Misuse of public procurement } \\
\text { procedure }\end{array}$ & 359 & Abuse of Official Position \\
\hline 265 & Money laundering & 366 & Trading in Influence \\
\hline 291 & Abuse of position and authority & 367 & Receipt of Bribes \\
\hline 292 & Illegal favoritism & 368 & Giving Bribes \\
\hline 293 & Receipt of Bribes & 156 & $\begin{array}{l}\text { Giving and receiving bribes related to } \\
\text { voting }\end{array}$ \\
\hline 294 & Giving Bribes & $228 \mathrm{a}$ & Abuse in the Privatization Process \\
\hline 295 & Trading in Influence & 230 & $\begin{array}{l}\text { Acceptance of a Bribe in the Execution } \\
\text { of Economic Activities }\end{array}$ \\
\hline 296 & Bribing for trading in influence & 231 & $\begin{array}{l}\text { Bribing in Execution of Economic } \\
\text { Activities }\end{array}$ \\
\hline
\end{tabular}


Law on Organization and Competence of State Bodies in Suppressing Organized Crime provides for the formation of Special Department of the Higher Public Prosecutor's Office for Combating Corruption and the Special Departments of the High Courts for the Suppression of Corruption. Police affairs related to the suppression of corruption are performed by the Office for the Fight against Organized Crime. Law on Withdrawal of Proceeds of the Criminal Offense is an important regulation that, among other things, regulates the seizure of property acquired by criminal offenses of corruption. Following strategic documents were adopted in the fight against this plague: National Anti- Corruption Strategy for 2013-2018 and the Action Plan for the Implementation of the Strategy from 2013 to 2018.

According to the more frequent corruptive offenses listed in the previous table, the compliance of incriminations with the legal regulation of EU is evident. In Croatia, the most often committed criminal offense of corruption is art.291 Abuse of position and authority. Second place is the criminal offense art.294. Giving Bribes, while in third place is the criminal offense art.293. Receipt of Bribes. In Serbia the most often committed criminal offense of corruption is art.359. Abuse of Official Position. Second place is the criminal offense art.227. Abuse of the Position of a Responsible Person, while in third place is the criminal offense art.367.

Receipt of Bribes. As can be seen from the comparative table, among incriminations in CC RS there aee no criminal offenses of Receiving and giving bribes in bankruptcy proceedings and Bribing for trading in influence, so the suggestion is to incorporate them into criminal law.

\section{Conclusion}

Corruption is today an indisputable social phenomenon that crosses the state borders and is justifiably considered a global problem. It has equally affected the public and private sector, developed and underdeveloped countries. Particularly affected are transition countries that did not have developed enough legal and institutional mechanisms to combat corruption. In our Region, corruption has progressed in all newly emerged states and has become a de facto way of life for a number of people, which has questioned the started reform of the legal system and the social order. In response to the challenges, risks and threats of acts of corruption, the legislator in Serbia and Croatia has adopted established international standards and solutions from previously signed and ratified documents. On this basis, the criminal law in those countries has been revised, and in this respect with the recent amendments of the CC the RS has criminalized seven new corruption-related offenses. In Serbia, the situation is somewhat more favorable because Croatia's earlier application for EU membership has aligned its legislation with EU regulations. In the prosecution of corrupt criminal offenses and their perpetrators in RC and RS, specialized bodies of detection and persecution have had a leading role, as well as the use of special investigative techniques and methods based on the US and developed EU countries. We are of the opinion that we should de lege ferenda adopt the Law on whistleblowers in Croatia as soon as possible, as done in Serbia, primarily for the protection of persons who report criminal offenses of corruption. It is necessary for Serbia to act according to the recommendations of GRECO experts from the last year's report and strengthen the independence of the courts and the independence of the prosecution, ensure the selection of staff according to professional standards and pursue the depoliticization of the judiciary.

\section{Acknowledgement}

This research has been fully supported by the Croatian Science Foundation, under the project no 1949 Multidisciplinary Research Cluster on Crime in Transition-Trafficking in Human Beings, Corruption and Economic Crime and project no 179045 Development of institutional capacity, standards and procedures for countering organized crime and terrorism in the conditions of international integration, Ministry of Education and Science, RS.

\section{References}

- Action Plan for 2017 and 2018 with the Strategy RC, OG No 60/17

- Adult offenders in the Republic of Croatia, reported, accused and convicted in 2017, National Bureau of Statistics, 2018.

- Adult offenders in the Republic of Serbia, reported, accused and convicted in 2017, National Bureau of Statistics, 2018.

- Anić Š, Klaić N, Domović Ž, Rječnik stranih riječi, Zagreb, 2002, p.752.

- Aristotel, Politika, NIO Kultura, Beograd, 1960, p. 1270. 
- Božić V, Criminal Offense of Bribery Focusing on Corruption of Family Physicians by Pharmaceutical Industries, Godišnjak Akademije pravnih znanosti, Vol.VI, no 1, Zagreb, p.101-150.

- Božić V, Kesić T, The Criminal Justice Responses to Corruption with Proposals de lege ferenda, Zbornik radova, Tara, 2016, p. 455-483.

- Božić V, Nikač Ž, Criminal incriminations based on the UN Convention against Transnational organized crime in the criminal legislation of the Republic of Croatia and the Republic of Serbia, FB Skopje, International scientific conference "St.Clement's messages for ethics, moralityand values" Conference proceedings, Skopje, 2016, p.89111

- Božić V, Nikač Ž, Criminal liability for bribery as a reward for promised service, 2017, Conference proceedings "Services and Rules on Services" Kragujevac, Pravni fakultet, p. 925-943.

- Božić V, Nikač Ž, Fight Against Corruption in the Area of the Region with Particular Reference to Croatia and Serbia, Istraživački centar Banja Luka, Collected papers, p.359- 380.

- Civil Law Convention on Corruption, CoE, 1999, ETS 174.

- Conclusion of the Government RS 05 no.110-7203/13, 25.08.2013.

- Council Framework Decision 2002/465 / PUP of 13 June 2002

- Council Framework Decision 2005/212/PUP of 24 February 2005, SL L 68, 15. 3. 2005 Crossref

- Criminal Code RS, OG No 85/05, 88/05, 107/05, 72/09, 111/09, 121/12, 104/13, 108/14, 94/16

- Criminal Law Convention on Corruption, CoE, 1999, ETS 173.16. Criminal Code RC, OG No $125 / 11,144 / 12,56 / 15,61 / 15,101 / 17$

- Criminal Procedure Code RC, OG No 152/08, 76/09,80/11, 121/11, 91/12, 143/12, 56/13, 145/13, 152/14, 70/17

- Criminal Procedure Code RS, OG No 72/11, 101/11, 121/11, 121/12, 32/13, 45/13, 55/14

- Derenčinović D, Mit o korupciji, 2001, p.36-38.

- Ignjatović Đ, Kriminologija, Pravni fakultet, Beograd, 2015.

- Law on Access to Information RC, OG No 25/13, 85/15

- Law on International Legal Assistance in Criminal Matters RC, OG No 178/04

- Law on Organization and Competence of State Bodies in Suppressing Organized Crime RS, OG No 94/16

- Law on Prevention of Money Laundering and Financing of Terrorism RC, OG No 108/17

- Law on Responsibility of Legal Persons for Criminal Offenses RC, OG No 151/03, 110/07, 45/11, 143/12

- Law on the Anti-Corruption Agency RS, OG No 97/08, 53/10, 66/11, 67/13, 112/13, 8/15

- Law on the Prevention of Conflict of Interest in Public Functions RC, OG No 26/11, 12/12, 124/12, 48/13, 57/15

- Law on the Program for the Protection of Participants in Criminal Procedure RS, OG No 85/05

- Law on the Protection of Whistleblowers RS, OG No 128/14

- Law on USKOK RC, OG No 76/09, 116/10, 145/10, 57/11, 136/12, 148/13, 70/17

- Law on Withdrawal of Proceeds of the Criminal Offense RS, OG No 32/13, 94/16

- Milutinović M, Kriminologija, Beograd, 1990

- National Anti-Corruption Strategy RS for 2013-2018 and the Action Plan for the Implementation of the Strategy from 2013 to 2018.

- Nikač Ž, Božić V, Simić B, Joint investigative teams as a mechanism of The UN Convention against transnational organized crime, 7th International Scientific Conference Archibald Reiss Days, Conference Proceedings, Tom 2, p. 269-283.

- Poup J, Anti Corruption Manual-Confronting Corruption or a Social Integrity System, Transparentnost Srbija, Beograd, 2004, p.3.

- The Strategy for the Suppression of Corruption RC from 2015 to 2020, OG No 26/15

- UNCAC, UN Treaty Series, 2003, vol. 2349, 41; Doc. A/58/422

- UNCATOC, UN Treaty Series, 2000, vol.2225.

- Witness Protection Act, OG No 163/03, 18/11, 73/17 